\title{
Transport of Nitrogen Compounds through Subsoils in Agricultural Areas: Column Tests
}

\author{
Joanna Fronczyk*, Anna Sieczka, Mariusz Lech, \\ Maja Radziemska, Zbigniew Lechowicz \\ Faculty of Civil and Environmental Engineering, Warsaw University of Life Sciences, \\ Nowoursynowska 159, 02-776 Warsaw, Poland
}

Received: 29 January 2016

Accepted: 22 March 2016

\begin{abstract}
Soil parameters in agricultural areas play an important role in the migration of nitrogen compounds to groundwater. Nitrogen loss from subsoil depends on soil permeability, organic content, and soil saturation. Our study evaluates the parameters controlling the migration of nitrogen compounds through selected fine and sandy soils that may affect the quality of groundwater in agricultural areas. The results of this study indicate that denitrification processes that substantially affect ammonium $\left(\mathrm{NH}_{4}^{+}\right)$and nitrate $\left(\mathrm{NO}_{3}^{-}\right)$ concentrations take place in fine soils. These processes decrease the flow of nitrogen into groundwater and are indicated by the production of a gashouse phase, a decrease in hydraulic conductivity, and a nitrogen compound concentration in the filtrate that is lower than the maximum concentration. Column tests have shown that the dominant transport process for silt loam and sand samples was advection, and the dominant transport process for loam was dispersion. Moreover, the velocities of $\mathrm{NH}_{4}^{+}$ion transport were lower than the velocities of water flow by approximately seven and five times for loam and sand, respectively. The estimated values of the retardation factor and dynamic sorption capacity for $\mathrm{NO}_{3}^{-}$were lower than those for $\mathrm{NH}_{4}^{+}$ions. Finally, groundwater located below the silt loam and loam soil layers can effectively be protected against the infiltration of nitrogen compounds from agricultural sources.
\end{abstract}

Keywords: groundwater contamination, fertilization, fine soils, breakthrough curve

\section{Introduction}

To control and manage groundwater quality it is necessary to recognize pollution and identify the factors influencing the concentrations of nitrogen compounds in groundwater - above all nitrates $\left(\mathrm{NO}_{3}{ }^{-}\right)$. Agriculture

*e-mail: joanna_fronczyk@sggw.pl is commonly considered a branch of economics that negatively interacts with the environment, especially due to contamination from nutrients (nitrogen and phosphorus compounds) and pesticides [1-3]. The most common forms of inorganic nitrogen in the environment are ammonium $\left(\mathrm{NH}_{4}^{+}\right)$, nitrite $\left(\mathrm{NO}_{2}^{-}\right)$, and $\mathrm{NO}_{3}^{-}$ions. The concentrations of the different forms of nitrogen lost from agroecosystems via leaching decrease according to the following order: $\mathrm{NO}_{3}^{-}$and $\mathrm{NO}_{2}^{-}>\mathrm{NH}_{4}^{+}>$organic 
nitrogen [4]. According to Camargo and Alonso [5], Moradzadeh et al. [6], and Matysik et al. [7], the concentrations of these ions in surface and groundwater increase worldwide, affecting aquatic organisms and ecosystem quality. Therefore, following the ratification of the Nitrates Directive [8], the EU member states have committed themselves to regularly assessing groundwater and surface water pollution by nitrogen compounds from agricultural sources. Moreover, the EU Water Directive implies the application of sustainable development principles in managing surface and groundwater and has determined a precise schedule of activities to ensure good aquatic ecosystem quality throughout Europe in 2015. The proposed activities include studies aimed at reducing $\mathrm{NO}_{3}^{-}$ concentrations in areas used for agricultural purposes.

The most important goal of sustainable agriculture is to improve nitrogen use efficiency and decrease nitrogen leaching into surface waters and underlying aquifers, in which it contributes to the contamination and eutrophication of aquatic systems. Inorganic nitrogen compounds may be removed from soil by plants, runoff, leaching, erosion, and gaseous loss, or may accumulate on mineral particles and organic matter surfaces. Leaching of nitrogen compounds from farmlands takes place through the gradual movement of $\mathrm{NO}_{3}^{-}$ions to deeper soil layers. Therefore, to assess the impact of pollution from fertilizers on surface and groundwater quality, it is necessary to monitor the soil nitrogen cycle and the migration of nitrogen in the aquifer [9-11]. The quantity of dissolved inorganic nitrogen transported into the saturated zone, particularly $\mathrm{NO}_{3}^{-}$, is predominately controlled by denitrification [12] and microbial $\mathrm{NO}_{3}^{-}$ reduction to nitric oxide $(\mathrm{NO})$, nitrous oxide $\left(\mathrm{N}_{2} \mathrm{O}\right)$, or dinitrogen $\left(\mathrm{N}_{2}\right)$. The transformation of $\mathrm{NO}_{3}^{-}$in the unsaturated zone is well recognized [9]. Additionally, Bernard-Jannin et al. [13] have indicated that land-use and aquifer parameters are the primary determinants of $\mathrm{NO}_{3}^{-}$ concentrations in subsurface aquifers. Similarly, PochMassegú et al. [14] and Chen et al. [15] have demonstrated that the hydrogeological characteristics of the substrate, volume, and frequency of rainfall, soil structure, flow of groundwater, and accumulation of $\mathrm{NO}_{3}{ }_{3}^{-}$in the soil profile influence groundwater $\mathrm{NO}_{3}^{-}$concentrations. The main parameters that affect the migration of contaminants include soil particle distribution, hydraulic permeability, preferential flow paths, and sorption capacity of mineral and organic particles $[16,17]$. Processes responsible for the movement of pollutants via mass flow in permeable soils are advection and dispersion, whereas diffusion processes are dominant in soils with low permeability [18]. A lower rate of water flow through fine soils can increase the retention time of dissolved contaminants in soil pores, which allows them to participate in biochemical processes (e.g., denitrification processes) that are insignificant in highly permeable soils. In the case of pollutants (inter alia nitrogen compounds) that participate in physicochemical and biological reactions, the saturation degree of the soil (oxygen availability), the presence of organic carbon and nutrients, and microbial activity are also important [16, 19].
According to Cui et al. [20], vertical and horizontal flow through the subsoil may be a crucial migration pathway of land-applied nitrogen. Furthermore, the soil nitrogen cycle is an integral part of nature that can be affected by agricultural activity $[21,22]$. Burgin and Hamilton [23] have indicated that $\mathrm{NO}_{3}^{-}$leaching from agricultural areas not only influences surface water eutrophication but also causes an increase in indirect $\mathrm{N}_{2} \mathrm{O}$ emissions to the atmosphere after denitrification.

We undertook this research to obtain a better understanding of the transport of $\mathrm{NO}_{3}^{-}$and $\mathrm{NH}_{4}^{+}$in saturated porous media in three different agricultural soils. The specific objectives of this study were as follows:

1. To determine nitrogen compounds removal capacities of three soils with different clay contents.

2. To determine changes in soil hydraulic conductivity during the permeation of an ammonium nitrate solution.

3. To estimate the soil flow parameters $\left(v, D, R\right.$, and $\left.S_{\mathrm{m}}\right)$ for nitrogen compounds by using tracer breakthrough curves.

\section{Material and Methods}

In March and September 2014, two undisturbed soil samples (diameter $89 \mathrm{~mm}$, length $0.6 \mathrm{~m}$ ) were collected in triplicate using a stainless steel tube sampler in the Imielin experimental site (Central Poland: 52 $04.650^{\prime} \mathrm{N}$ $\left.21^{\circ} 10.767^{\prime} \mathrm{E}\right)$. The conditions at the experimental site and the depth of the soil sampling are shown schematically in Fig. 1. To avoid drying, the samples were sealed in plastic cups and stored in a chamber with a constant humidity of $95 \%$ at $10^{\circ} \mathrm{C}$. In addition, a Vistula sand sample was used as the comparative sample. In the laboratory, particle size distribution, bulk density, and loss on ignition at $550^{\circ} \mathrm{C}$ of the collected soil samples were determined.

\section{Batch Tests}

The laboratory procedure for batch testing was applied to obtain reaction kinetics for the three soil samples. In these tests, $50 \mathrm{~mL}$ of an ammonium nitrate solution (52 mg NH$+\cdot \mathrm{L}^{-1}$ and $100 \mathrm{mg} \mathrm{NO} \cdot \cdot \mathrm{L}^{-1}$ ) was mixed with $5 \mathrm{~g}$ of a soil sample (air dried, crushed, and sieved through a $1 \mathrm{~mm}$ sieve) at room temperature. Batches were run in duplicate using a solid-to-liquid ratio of 1:10. Analogously, a blank and a control test were prepared using the treatment solution (without a soil sample) and a soil sample with distilled water, respectively. Shaking at a speed of $14 \mathrm{~min}^{-1}$ (on a rotary shaker GFL 3040) was carried out for designated periods of $1,4,8,16,24$, and 48 hours, which were selected according to the U.S. Environmental Protection Agency [24]. After the shaking period, the working solutions were filtered through paper filters and prepared for chemical analysis. The test results were used to define the kinetics of the occurring biochemical reaction and the sorption capacity of the tested soils. The kinetics of the removal process were analysed using the pseudosecond order model described by the following equation: 


$$
\frac{t}{q_{t}}=\frac{1}{K_{P S O q_{e q}^{2}}^{2}}+\frac{t}{q_{e q}}
$$

...where $q_{t}$ is the sorption capacity determined after time $t\left(\mathrm{mg} \cdot \mathrm{g}^{-1}\right), K_{\mathrm{PSO}}$ is the equilibrium rate constant of the pseudo second-order model $\left(\mathrm{g} \cdot \mathrm{mg}^{-1} \cdot \mathrm{hr}^{-1}\right)$, and $q_{e q}$ is the equilibrium sorption capacity of the $\mathrm{NH}_{4}^{+}$ions $\left(\mathrm{mg} \cdot \mathrm{g}^{-1}\right)$.

\section{Batch Incubation}

The soil samples for the batch incubation experiment were prepared in the same way as those for the batch tests. Each part of a dry soil sample ( $5 \mathrm{~g}$ ) was transferred into $250 \mathrm{~mL}$ polyethylene bottles and mixed with $5 \mathrm{~mL}$ distilled water to provide saturation conditions. Each bottle was sealed, and then the mixture was pre-incubated in the dark at room temperature for seven days to establish microbial activity. After the pre-incubation period, an ammonium nitrate solution (with the same concentration as used in the batch tests) was added to each bottle at a rate of 1:5 (soil-to-solution) and stored in the dark under the same conditions as those used in the pre-incubation process. At each desired incubation time $(1,4,7,10,15,20$, and 30 days) the treatment solutions were removed from the bottles for laboratory testing to track temporal changes and variations in the selected parameters.

\section{Column Tests}

Saturated hydraulic conductivity tests were performed using the constant head method $(\mathrm{i}=10)$ according to the ASTM D5084-00 [25] standard in a flexible-wall permeameter, a scheme of which is shown in Fig. 2. Due

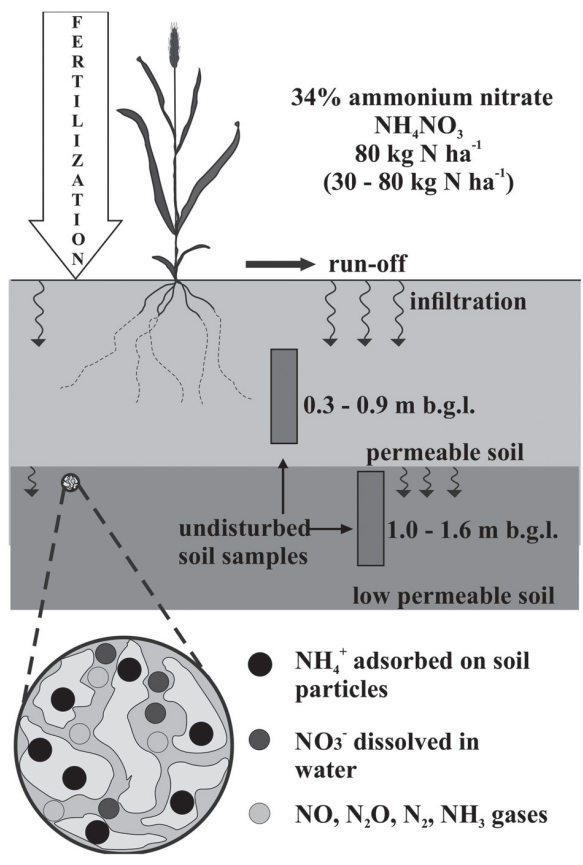

Fig. 1. Schematic diagram of the experimental site conditions and soil sampling depth.

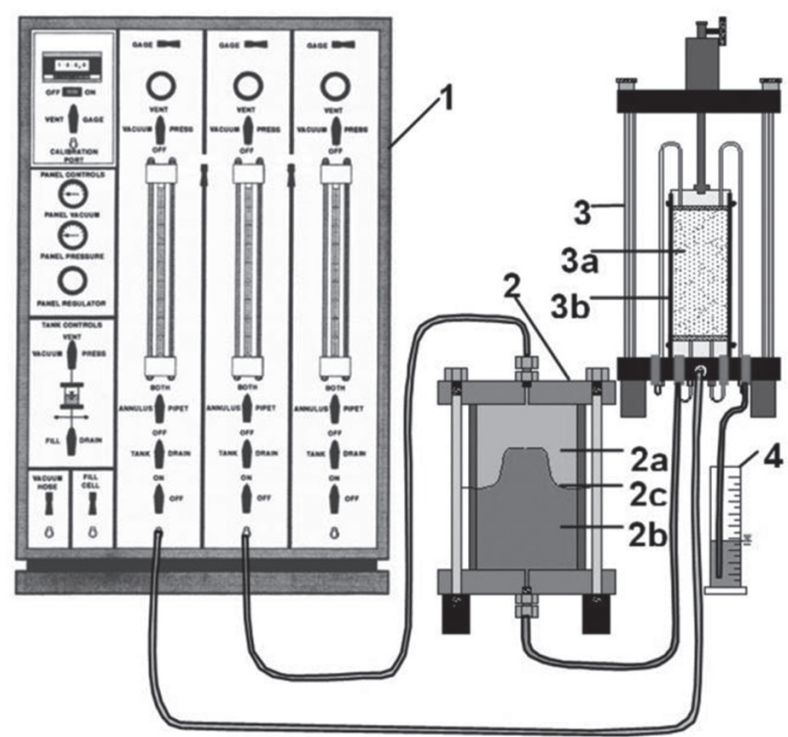

Fig. 2. Scheme of a flexible-wall permeameter: 1-control panel, 2-bladder accumulator, 2a-water, 2b-liquid other than water, 2c-elastic membrane, 3-chamber, 3a-sample, 3b-latex membrane, 4-measuring cylinder (acc. to Trautwein Soil Testing Equipment Co.) [26].

to the aggressive nature of the solutions it was necessary to use equipment made from stainless steel and the PMMATrautwein system [27]. Before testing, the specimens were pre-saturated with distilled water until a constant flow was established through the samples. Moreover, to imitate the stress conditions in the subsoil a confining pressure of 40 $\mathrm{kPa}$ was applied. During the study, the flow of the solution from the bottom to the top of the sample was used. After establishing steady state flow conditions a chloride ion solution $\left(100 \mathrm{mg} \mathrm{Cl}^{-} \cdot \mathrm{L}^{-1}\right)$ and then an ammonium nitrate solution $\left(100 \mathrm{mg} \mathrm{NO}_{3}^{-} \cdot \mathrm{L}^{-1}, 52 \mathrm{mg} \mathrm{NH}{ }_{4}^{+} \cdot \mathrm{L}^{-1}\right)$ were injected as pulse and step inputs, respectively. Effluent liquid samples for chemical analysis were collected to a $100 \mathrm{~mL}$ glass cylinder at different time intervals for each sample tested. Sampling frequency depended mostly on the flow rate and the volume of the liquid that passed through the sample during the test: two effluent samples per day were taken for silt loam, and 12 effluent samples daily for loam and sand. After the contaminants transport test the soil samples were analysed for nitrogen compounds.

The hydraulic conductivity test and contaminants transport test results were presented relative to the pore volume of the flow as a breakthrough curve (BTC). On the basis of the results, the parameters of the advectiondispersion equation of contaminant transport in groundwater were determined using the CXTFIT software package [28], which uses a nonlinear, least-square inverse parameter estimation method from the observed concentration data:

$$
R \frac{\partial C}{\partial t}=D \frac{\partial^{2} C}{\partial z^{2}}-v \frac{\partial C}{\partial z}
$$


...where $R$ is the retardation factor, $C$ is the concentration $\left(\mathrm{mg} \cdot \mathrm{L}^{-1}\right), t$ is time $(\mathrm{s}), z$ is the distance $(\mathrm{m})$, and $D$ is the coefficient of hydrodynamic dispersion $\left(\mathrm{m}^{2} \cdot \mathrm{s}^{-1}\right)$.

Simulation of the conservative tracer $(\mathrm{Cl})$ and nitrogen compounds $\left(\mathrm{NH}_{4}^{+}\right.$and $\left.\mathrm{NO}_{3}^{-}\right)$transport in the porous media columns was conducted assuming that the samples were initially homogeneous. During the inverse analysis of the transport equation parameters for the nonreactive tracer, the assumed value of the retardation coefficient $R$ was 1 . Calculations were performed to estimate the velocity of flow $(v)$, the hydrodynamic dispersion coefficient $(D)$, the retardation factor $(R)$, the longitudinal dispersivity $\left(\alpha_{\mathrm{L}}\right)$, and the Péclet number $\left(P_{e}\right)$ of the soil samples.

\section{Chemical Analysis}

The ammonium nitrate solution and the chloride solution used in laboratory studies were prepared by dissolving a granular $\mathrm{NH}_{4} \mathrm{NO}_{3}$ fertilizer $(34 \% \mathrm{~N})$ and $\mathrm{NaCl}$, respectively, in deionised water. Liquid samples collected in batch and column tests were analysed for their chloride (Mohr method), $\mathrm{NH}_{4}^{+}$(Nessler method), and $\mathrm{NO}_{3}^{-}$ (cadmium reduction method) contents using a DR 6000 UV-VIS spectrophotometer (Hach Lange, Düsseldorf, Germany) as well as $\mathrm{pH}$ and electrical conductivity (EC) using a 18.52.01 multimeter (Ejkelkamp, the Netherlands). The content of nitrogen compounds in the soil samples $\left(\mathrm{N}-\mathrm{NH}_{4}\right.$ and $\left.\mathrm{N}-\mathrm{NO}_{3}\right)$ was determined using colorimetric methods with Nessler's reagent and phenoldisulfonic acid, respectively. The $\mathrm{pH}$ of the soil samples was measured in a soil-to- $\mathrm{KCl}$ solution mixture (at a ratio of 1:2.5) and the EC in a soil-to-water mixture (at a ratio of 1:2) using an 18.52.01 multimeter (Eijkelkamp, the Netherlands). All used reagents were of analytical grade.

\section{Results and Discussion}

Selected physical properties of undisturbed soil samples (UDS1 and UDS2) collected at the Imielin experimental site and the sand sample are summarized in Table 1. According to U.S. Department of Agriculture soil survey staff [29], the tested soils were classified as silt loam, loam, and sand. For laboratory testing, soils with different clay contents (from $0 \%$ for sand to $21 \%$ for silt loam) and silt fractions (from $0 \%$ for sand to $66 \%$ for silt loam) were selected to facilitate examination of the impacts of the grain size distribution and saturated hydraulic conductivity on the intensity of nitrogen compounds migration. The grain size distributions are presented in Fig. 3. The measured range of soil hydraulic conductivity extended from $2.3 \cdot 10^{-8} \mathrm{~m} \cdot \mathrm{s}^{-1}$ for silt loam to $4.0 \cdot 10^{-5} \mathrm{~m} \cdot \mathrm{s}^{-1}$ for sand. According to Eurocode 7 [30], soils with organic matter contents (measured by loss on ignition) at $2 \%$ to $6 \%$ are classified as low organic soils. The soils marked as UDS1 and UDS2, which were characterized by loss on ignition at $3.1 \%$ and $2.3 \%$, respectively, can be placed in this class. The $\mathrm{pH}$ values for the UDS1 and UDS2 samples were alkaline (7.35 and 7.54, respectively), and the $\mathrm{pH}$ of the sand was neutral. Moreover, the soils had low EC values.

\section{Batch Tests}

The kinetic rate constants obtained from the pseudo second-order (PSO) kinetic model with estimated values of the coefficient of determination $R^{2}$ and the initial sorption

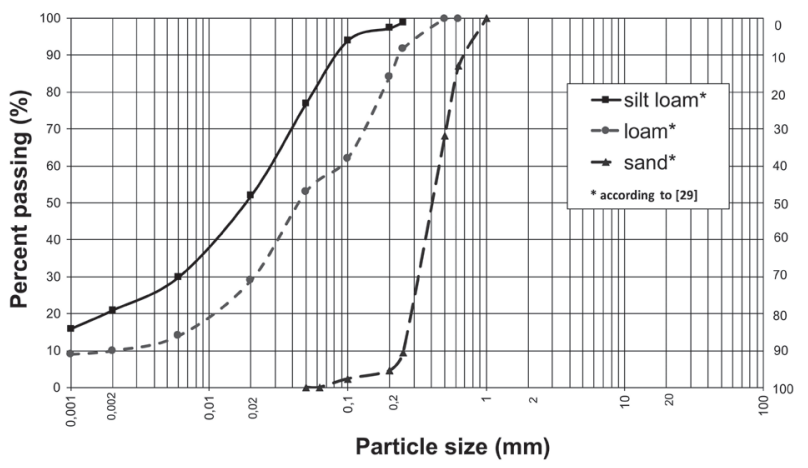

Fig. 3. Grain size distribution of the tested soils.

Table 1. Physical properties of the undisturbed soil samples and sand sample.

\begin{tabular}{|c|c|c|c|}
\hline Parameter & UDS1 & UDS2 & Sand \\
\hline $\begin{array}{c}\text { Fraction content }(\%) \text { : } \\
\text { Sand } \mathrm{Sa}(1.0-0.063 \mathrm{~mm}) \\
\text { Silt } \mathrm{Si}(0.063-0.002 \mathrm{~mm}) \\
\text { Clay } \mathrm{Cl}(<0.002 \mathrm{~mm}) \\
\text { Soil type }\end{array}$ & $\begin{array}{c}13 \\
66 \\
21 \\
\text { silt loam } \\
\end{array}$ & $\begin{array}{c}43 \\
47 \\
10 \\
\text { loam } \\
\end{array}$ & $\begin{array}{c}100 \\
0 \\
0 \\
\text { sand } \\
\end{array}$ \\
\hline Bulk density $\left(\mathrm{Mg} \cdot \mathrm{m}^{-3}\right)$ & 1.63 & 1.60 & 1.71 \\
\hline Porosity & 0.40 & 0.40 & 0.34 \\
\hline Saturated hydraulic conductivity $\left(\mathrm{m} \cdot \mathrm{s}^{-1}\right)$ & $2.3 \cdot 10^{-8}$ & $3.9 \cdot 10^{-6}$ & $4.0 \cdot 10^{-5}$ \\
\hline $\mathrm{pH}(1: 2.5 \mathrm{KCl})$ & 7.35 & 7.54 & 7.15 \\
\hline Electrical conductivity $(1: 2$ water $)\left(\mu \mathrm{S} \cdot \mathrm{cm}^{-1}\right)$ & 363 & 160 & 154.5 \\
\hline Loss on ignition $+550^{\circ} \mathrm{C}(\%)$ & 3.1 & 2.3 & 0.1 \\
\hline
\end{tabular}


Table 2. Kinetic constants of ammonium ions removal.

\begin{tabular}{|c|c|c|c|}
\hline Pseudo second order kinetic model & UDS1 & UDS2 & sand \\
\hline Equilibrium rate constant $k_{\mathrm{PSO}}\left(\mathrm{g} \cdot \mathrm{mg}^{-1} \mathrm{hr}^{-1}\right)$ & 1.163 & 1.305 & 1.007 \\
\hline Calculated equilibrium sorption capacity $q_{\mathrm{eq}}\left(\mathrm{mg} \cdot \mathrm{g}^{-1}\right)$ & 0.121 & 0.110 & 0.089 \\
\hline $\mathrm{R}^{2}$ & 0.931 & 0.925 & 0.937 \\
\hline Initial sorption rate constant $v_{\mathrm{o}}\left(\mathrm{mg} \cdot \mathrm{g}^{-1} \mathrm{hr}^{-1}\right)$ & 0.017 & 0.016 & 0.008 \\
\hline
\end{tabular}

rate constant $v_{0}=K_{P S O} \cdot q_{\text {eq }}^{2}\left(\mathrm{mg} \cdot \mathrm{g}^{-1} \mathrm{hr}^{-1}\right)$ are given in Table 2 , and the pseudo second-order plots for $\mathrm{NH}_{4}^{+}$removal are presented in Fig. 4. The kinetic tests showed that the amount of re-moved $\mathrm{NH}_{4}^{+}$ions increased for 24 hours and then did not change significantly. Based on the coefficients of determination $R^{2}$ of the PSO kinetic model in the range of 0.925 to 0.937 , this model may be applied to describe the removal processes of $\mathrm{NH}_{4}^{+}$. Moreover, a good correlation between the test data and the PSO model suggested that pore diffusion was an important element in the removal process [31] and that the removal process represented chemisorption rather than physisorption and that the sorption followed the Langmuir equation [32]. Table 2 shows that the highest $\mathrm{NH}_{4}^{+}$sorption capacity $q_{\text {eq }}$ and the initial sorption rate constant $v_{\mathrm{o}}$ were observed for sample UDS1 $\left(0.121 \mathrm{mg} \cdot \mathrm{g}^{-1}\right.$ and $0.017 \mathrm{mg} \cdot \mathrm{g}^{-1} \cdot \mathrm{hr}^{-1}$, respectively), followed by sample UDS2 $\left(0.110 \mathrm{mg} \cdot \mathrm{g}^{-1}\right.$ and $\left.0.016 \mathrm{mg} \cdot \mathrm{g}^{-1} \cdot \mathrm{hr}^{-1}\right)$ and sand sample $\left(0.089 \mathrm{mg} \cdot \mathrm{g}^{-1}\right.$ and $\left.0.008 \mathrm{mg} \cdot \mathrm{g}^{-1} \cdot \mathrm{hr}^{-1}\right)$. These values were strongly correlated with the organic matter and clay fraction contents, as stated by Zhang et al. [33]. In addition, the studies have reported higher $\mathrm{NH}_{4}^{+}$sorption capacities for natural soils, specifically for lake alluvial sandy earth $0.658 \mathrm{mg} \cdot \mathrm{g}^{-1}$ and granitic sandy earth $0.098 \mathrm{mg} \cdot \mathrm{g}^{-1}$ soils.

\section{Batch Incubation}

The incubation test results presented in Fig. 5 have clearly shown that $\mathrm{NO}_{3}^{-}$removal was negligible for all three soil samples. During the first 20 days the $\mathrm{NO}_{3}^{-}$ removal rate varied from 0 to $22 \%$. After 30 days of

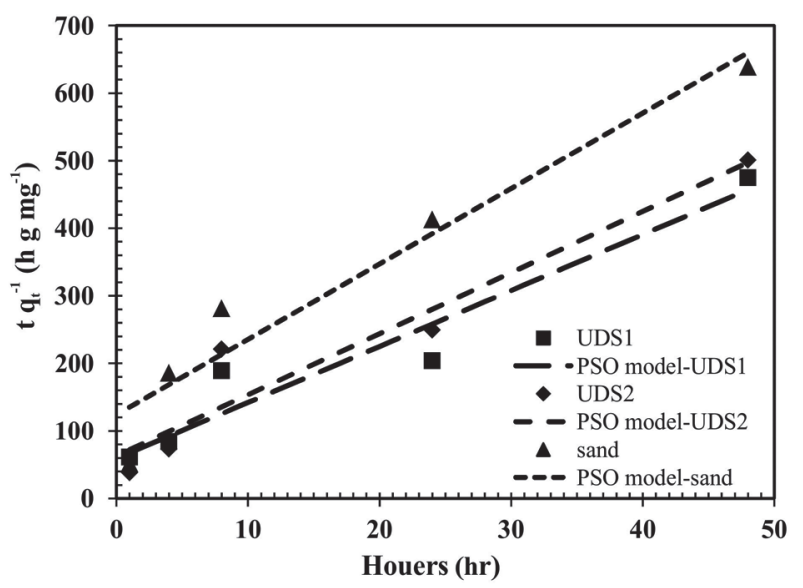

Fig. 4. Kinetics of ammonium ion removal by soil samples. incubation the concentration rapidly increased to values higher than the initial concentration $\left(128 \mathrm{mg} \cdot \mathrm{L}^{-1}\right.$ for UDS 1 , $166 \mathrm{mg} \cdot \mathrm{L}^{-1}$ for UDS2, and $116 \mathrm{mg} \cdot \mathrm{L}^{-1}$ for sand). This considerable increase could be ascribed to nitrification because no adjustment of $\mathrm{NO}_{3}^{-}$ions was observed in the batch incubation system. However, this phenomenon was not observed by Lee et al. [17].

The $\mathrm{NH}_{4}^{+}$concentration in the solution after the desired incubation time decreased relatively to the initial concentration. The removal ratios fluctuated from 14 to $35 \%$ for sample UDS1, from 3 to $30 \%$ for sample UDS2, and from 1 to $18 \%$ for the sand sample. The highest degree to which $\mathrm{NH}_{4}^{+}$ions were removed by UDS1 could result from the largest organic matter and clay contents. Sorption processes could occur with greater intensity on clay particles than on the sandy materials.
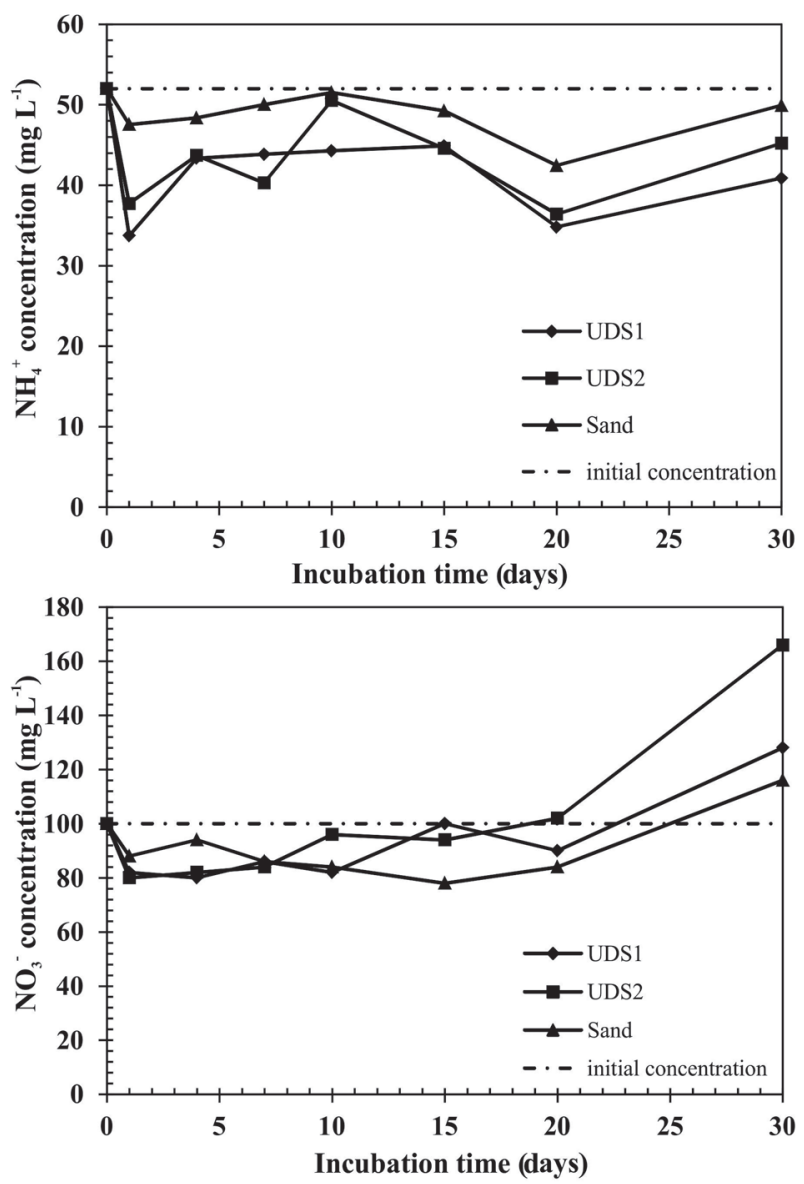

Fig. 5. Ammonium and nitrate concentrations during batch incubation. 


\section{Column Tests}

Fig. 6 presents the test results for hydraulic conductivity changes and for the transport of chloride (non-reactive tracer) and nitrogen compounds (reactive tracers) through texturally different soil samples. This figure shows the changes of the average values of the parameters as a function of the total pore volume of flow (PVF) while accounting for the two stages of the study: 1) filtration of the non-reactive tracer (chloride ions) and 2) filtration of the reactive traces $\left(\mathrm{NO}_{3}{ }^{-}\right.$and $\left.\mathrm{NH}_{4}{ }^{+}\right)$. The hydraulic conductivity $k$ of the soil with low permeability (UDS 1 silt loam) was $2.3 \cdot 10^{-8} \mathrm{~m} \cdot \mathrm{s}^{-1}$. This value steadily decreased during the flow of the reactive tracers to $3.1 \cdot 10^{-9} \mathrm{~m} / \mathrm{s}$. After replacing the pore fluid one and a half times $(\mathrm{PVF}=1.5)$, the changes of $k$ were insignificant. The changes observed for highly permeable soil samples (UDS 2 loam) were different. At the beginning of the test, the $k$ value slightly increased (from $3.9 \cdot 10^{-6} \mathrm{~m} \cdot \mathrm{s}^{-1}$ to $4.9 \cdot 10^{-6} \mathrm{~m} \cdot \mathrm{s}^{-1}$ ) and then remained constant until the PVF equalled 12.5 . In the last stage of the study $k$ decreased to $1.8 \cdot 10^{-6} \mathrm{~m} \cdot \mathrm{s}^{-1}$. The observed decrease in $k$ for both samples could be caused by nitrogen volatilization $\left(\mathrm{NH}_{3}, \mathrm{~N}_{2}\right.$, and $\mathrm{N}_{2} \mathrm{O}$ ), which depends on the rate of fertilizer application and soil properties [4, 34].

Fig. 5 illustrates that the transport of chloride ions and nitrogen compounds $\left(\mathrm{NO}_{3}{ }^{-}\right.$and $\left.\mathrm{NH}_{4}^{+}\right)$through the undisturbed soil samples and the sand sample at steadystate saturation conditions was different. We predicted the flow velocity and coefficient of hydrodynamic dispersion of the soil samples based on the chloride BTCs, and we also calculated the longitudinal dispersivity $\left(\alpha_{\mathrm{L}}\right)$ and Péclet number $\left(P_{e}\right)$ (Table 3$)$. The chloride BTCs were similarly symmetric, and their analyses showed that the equilibrium model could be applied to these soil samples. The shape of the chloride BTC for the sand sample was a typical Gaussian distribution, and for the undisturbed soil samples it was a Gaussian distribution with tails. This could be due to the preferential flow that occurred in the undisturbed soil samples and may have been caused by unequal flow velocity. The observations are consistent with the reports of Cheng et al. [35]. According to Mon et al. [36] there was no preferential flow through the sand sample, because the relative concentration of chloride $\left(\mathrm{C} / \mathrm{C}_{0}\right)$ was about
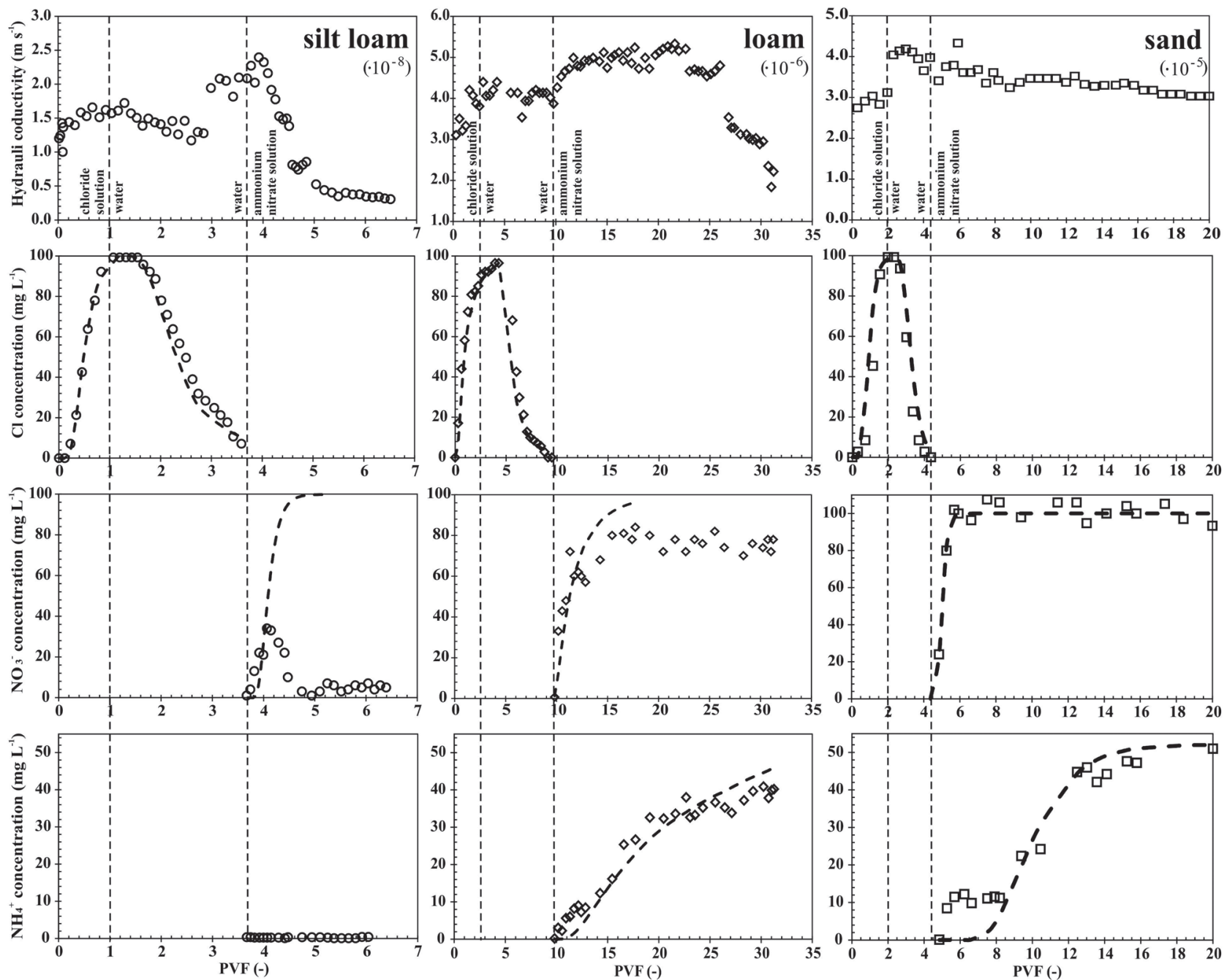

Fig. 6. Hydraulic conductivity changes, fitted (dotted line) and observed (points) breakthrough curves of the non-reactive tracer (chlorides), and reactive tracers (nitrate and ammonium): $100 \mathrm{mg} \mathrm{Cl} \cdot \mathrm{L}^{-1}, 100 \mathrm{mg} \mathrm{NO}_{3}^{-} \cdot \mathrm{L}^{-1}$, and $52 \mathrm{mg} \mathrm{NH}_{4}^{+} \cdot \mathrm{L}^{-1}$. 
Table 3. Transport parameters predicted for soil samples using the CXTFIT model.

\begin{tabular}{|c|c|c|c|c|}
\hline \multirow[b]{2}{*}{ Parameter } & \multicolumn{2}{|c|}{ UDS 1} & \multirow[b]{2}{*}{ UDS2 } & \multirow[b]{2}{*}{ Sand } \\
\hline & $\begin{array}{l}\text { Saturation with } \\
\mathrm{Cl} \text { solution }\end{array}$ & $\begin{array}{l}\text { Leaching of } \\
\mathrm{Cl} \text { solution }\end{array}$ & & \\
\hline \multicolumn{5}{|c|}{ Flow parameters estimated from the breakthrough curve of $\mathrm{Cl}$} \\
\hline Velocity of flow $v\left(\mathrm{~m} \cdot \mathrm{s}^{-1}\right)$ & $7.04 \cdot 10^{-7}$ & $2.56 \cdot 10^{-7}$ & $6.50 \cdot 10^{-5}$ & $2.64 \cdot 10^{-4}$ \\
\hline $\begin{array}{l}\text { Coefficient of hydrodynamic } \\
\text { dispersion } D\left(\mathrm{~m}^{2} \cdot \mathrm{s}^{-1}\right)\end{array}$ & $3.78 \cdot 10^{-9}$ & $2.06 \cdot 10^{-9}$ & $3.32 \cdot 10^{-6}$ & $1.67 \cdot 10^{-6}$ \\
\hline Coefficient of determination $\mathrm{R}^{2}$ & 0.99 & 0.99 & 0.96 & 0.91 \\
\hline Longitudinal dispersivity $\alpha_{\mathrm{L}}(\mathrm{m})$ & 0.005 & 0.008 & 0.051 & 0.006 \\
\hline Péclet number $P_{e}$ & 11.06 & 7.39 & 2.47 & 15.04 \\
\hline \multicolumn{5}{|c|}{ Transport parameters estimated from the breakthrough curve of $\mathrm{NH}_{4}^{+}$} \\
\hline Retardation factor $\mathrm{R}$ & n.p..$^{a}$ & n.p..$^{a}$ & 6.994 & 5.081 \\
\hline Coefficient of determination $\mathrm{R}^{2}$ & n.p. ${ }^{a}$ & n.p. ${ }^{a}$ & 0.91 & 0.81 \\
\hline $\begin{array}{l}\text { Dynamic sorption capacity } \\
\left(\text { for C }=0.1 \mathrm{C}_{0}\right) S_{\mathrm{m}}\left(\mathrm{mg} \cdot \mathrm{kg}^{-1}\right)\end{array}$ & n.p. ${ }^{\text {a }}$ & n.p..$^{a}$ & 17.31 & 2.70 \\
\hline \multicolumn{5}{|c|}{ Transport parameters estimated from the breakthrough curve of $\mathrm{NO}_{3}^{-}$} \\
\hline Retardation factor $\mathrm{R}$ & 0.909 & 0.359 & 1.468 & 0.577 \\
\hline Coefficient of determination $\mathrm{R}^{2}$ & 0.64 & 0.72 & 0.58 & 0.89 \\
\hline $\begin{array}{l}\text { Dynamic sorption capacity } \\
\left(\text { for C }=0.1 \mathrm{C}_{0}\right) S_{\mathrm{m}}\left(\mathrm{mg} \cdot \mathrm{kg}^{-1}\right)\end{array}$ & \multicolumn{2}{|c|}{2.83} & 5.12 & 3.74 \\
\hline
\end{tabular}

${ }^{a}$ n.p., not predicted.

0.5 for PVF less than 1. The maximum chloride concentration in the effluent was measured after PVF equalled 1 for the UDS1 sample, 4 for the UDS2 sample, and 2 for the sand sample. Calculation of the flow parameters for the entire chloride BTC for sample UDS1 was impossible; thus, the results were interpreted in two steps: 1) saturation of the sample with chloride solution and 2) leaching of chloride ions. Problems were potentially caused by the substantial change in the permeability coefficient of the sample at the stage of chloride ion leaching (Fig. 6). The shape of the BTC for UDS2 suggested that the sample was nonhomogeneous and layered [37].

Steady growth of the effluent concentration was observed until the effluent concentration reached $0.80 \mathrm{C}_{0}(\mathrm{PVF}=1.6)$. Then the effluent concentration increased slowly and reached a maximum concentration of $0.93 \mathrm{C}_{0}$ after the PVF reached 4 . The shape of the chloride ion-leaching curve was similar; first, the effluent concentration quickly decreased until the PVF reached $7\left(0.13 \mathrm{C}_{0}\right)$ and next the effluent concentration slowly decreased until PVF $=9$ and $\mathrm{C}=0 \mathrm{mg} \cdot \mathrm{L}^{-1}$. The tails could be caused by the interactions of the advective and diffusive transport of the solutes in the porous material. The flow parameters were estimated with determination coefficients of 0.91 to 0.99 . The estimated $\alpha_{\mathrm{L}}$ was similar for UDS1 and the sand sample. However, the value of $\alpha_{\mathrm{L}}$ for UDS2 was larger by one order of magnitude. This result may indicate that the sample was not heterogeneous.
Numerous studies indicated that the value of $\alpha_{\mathrm{L}}$ depends on the scale, and for the same materials this value is several orders of magnitude larger for field-scale than for lab-scale [38], which commonly ranges between 0.0001 and $0.010 \mathrm{~m}$ [39]. The values of $P_{e}$ (from 2.47 for UDS2 to 15.04 for the sand sample) suggested that advection was the dominant transport process for contaminants through the UDS1 and sand samples and that dispersion dominated over advection in the case of UDS2 [37]. The significantly different $P_{e}$ for UDS2 likely resulted from stratification and the heterogeneity of the sample.

After the tests with the non-reactive tracer were completed, the flow of the ammonium nitrate solution through the samples was started. The $\mathrm{NH}_{4}^{+}$and $\mathrm{NO}_{3}{ }_{3}^{-} \mathrm{BTCs}$ are presented in Fig. 6 . The effluent concentration of $\mathrm{NH}_{4}^{+}$ from sample UDS1 was $<0.04 \mathrm{mg} \cdot \mathrm{L}^{-1}$ for the duration of the study; therefore, it was not possible to calculate the removal parameters. The $\mathrm{NH}_{4}^{+}$ion concentration of zero resulted from the non-exhaustion of the sample sorption capacity. The added $\mathrm{NH}_{4}^{+}(12.80 \mathrm{mg})$ was fully retained on the sample material by using only part of the sample sorption capacity $\left(0.036 \mathrm{mg} \cdot \mathrm{g}^{-1}\right.$ of $0.121 \mathrm{mg} \cdot \mathrm{g}^{-1}$ calculated from the batch test). Using the BTCs for the UDS2 and sand samples, the retardation factor $R$ and dynamic sorption capacity for the breakthrough point $\left(\mathrm{C}=0.1 \mathrm{C}_{0}\right) S_{\mathrm{m}}$ were calculated. Based on the definition of the retardation factor [38], the velocity of $\mathrm{NH}_{4}^{+}$transport was less than the velocity of the water flow (6.99 and 5.08 times for UDS2 and the sand sample, respectively). The dynamic 
Table 4. Characteristics of the soil samples before and after the column tests.

\begin{tabular}{|c|c|c|c|c|c|}
\hline \multicolumn{2}{|c|}{ Sample } & $\mathrm{pH}(\mathrm{KCl})$ & $\begin{array}{c}\mathrm{EC} \\
\left(\mu \mathrm{S} \cdot \mathrm{cm}^{-1}\right)\end{array}$ & $\begin{array}{c}\mathrm{N}-\mathrm{NH}_{4} \\
\left(\mathrm{mg} \cdot \mathrm{kg}^{-1}\right)\end{array}$ & $\mathrm{N}-\mathrm{NO}_{3}\left(\mathrm{mg} \cdot \mathrm{kg}^{-1}\right)$ \\
\hline \multirow{3}{*}{ UDS1 } & $\mathrm{BCT}^{\mathrm{a}}$ & 7.35 & 362.95 & 0.58 & 0.35 \\
\cline { 2 - 6 } & $\mathrm{ACT}^{\mathrm{b}}$ & 6.95 & 220.8 & 11.98 & 2.38 \\
\hline \multirow{3}{*}{ UDS2 } & $\mathrm{BCT}^{\mathrm{a}}$ & 7.54 & 159.8 & 0.3 & 1.78 \\
\cline { 2 - 7 } & $\mathrm{ACT}^{\mathrm{b}}$ & 7.56 & 229.5 & 73.60 & 0.28 \\
\hline \multirow{3}{*}{ sand } & $\mathrm{BCT}^{\mathrm{a}}$ & 7.15 & 190.2 & $<0.1$ & $<0.25$ \\
\cline { 2 - 7 } & $\mathrm{ACT}^{\mathrm{b}}$ & 6.48 & 77.4 & 28.51 & 0.79 \\
\hline
\end{tabular}

${ }^{a} \mathrm{BCT}$ - before the column test

${ }^{\mathrm{b}} \mathrm{ACT}$ - after the column test

sorption capacity of UDS2 calculated for the exhaustion point $\left(\mathrm{C}=\mathrm{C}_{0}\right)$ was larger $\left(0.149 \mathrm{mg} \cdot \mathrm{g}^{-1}\right)$ than the sorption capacity calculated from the batch tests $\left(0.110 \mathrm{mg} \cdot \mathrm{g}^{-1}\right)$, which could indicate an overlap in other $\mathrm{NH}_{4}^{+}$ion removal processes. This result was confirmed by the documented maximum concentration in the effluent solution of $0.8 \mathrm{C}_{0}$. In contrast, the maximum effluent concentration of $\mathrm{NH}_{4}^{+}$ for the sand sample was equal to the influent concentration (52 $\left.\mathrm{mg} \cdot \mathrm{L}^{-1}\right)$, and the dynamic sorption capacity for the exhaustion point was smaller than the sorption capacity calculated from the batch test and commonly reported by other researchers $[40,41]$.

The estimated values of retardation factor $R$ and dynamic sorption capacity $S_{\mathrm{m}}$ for $\mathrm{NO}_{3}{ }^{-}$were smaller than those for the $\mathrm{NH}_{4}^{+}$ions. Due to its negative charge, $\mathrm{NO}_{3}^{-}$ is known to be more mobile in the soil-water environment than the positively charged $\mathrm{NH}_{4}^{+}$ions $[16,18,34]$. For $\mathrm{NO}_{3}^{-}$, an equal concentration in the effluent solution from the sand sample to the influent solution was achieved after $\mathrm{PVF}=1.3$. Further provision of the ammonium nitrate solution resulted in $\mathrm{NO}_{3}^{-}$leaching, with $\mathrm{NO}_{3}^{-}$effluent concentrations of $0.94 \mathrm{C}_{0}$ to $1.16 \mathrm{C}_{0}$. The shape of the $\mathrm{NO}_{3}^{-}$ BTCs for the undisturbed soil samples (particularly for UDS1) strongly suggested the occurrence of denitrification processes. The maximum effluent concentration $\left(0.34 \mathrm{C}_{0}\right)$ was reached after PVF $=0.5$. Next, the concentration decreased to $0.1 \mathrm{mg} \cdot \mathrm{L}^{-1}$. Simultaneously, the formation of gas bubbles was observed in the effluent pipes along with a significant decrease in hydraulic conductivity, which could indicate nitrogen volatilization $\left(\mathrm{NH}_{3}, \mathrm{~N}_{2}\right.$, and $\left.\mathrm{N}_{2} \mathrm{O}\right)$ [10].

Gas production in UDS2 was far less intense, but a decrease in hydraulic conductivity and an effluent concentration lower than the initial concentration $\left(0.80 \mathrm{C}_{0}\right)$ were observed. The obtained results were consistent with the results reported by Lee et al. [17] and confirmed that the mechanism of $\mathrm{NO}_{3}^{-}$removal depended on soil texture and that denitrification was a dominant removal process for $\mathrm{NO}_{3}^{-}$in fine-grained soils. Although a sufficiently large population of denitrifying bacteria, electron donor compounds (organic compounds), and restricted availability of oxygen were required for the denitrification in the soil [42], the intensity of gas production was higher in the soil samples with higher organic matter contents, and lower permeability increased the solution resistant time in soil pores, facilitating the denitrification processes.

Table 4 summarizes the physical and chemical properties of the soil samples before and after the column test. The set of test results shows that the contents of $\mathrm{N}-\mathrm{NH}_{4}$ and $\mathrm{N}_{-} \mathrm{NO}_{3}$ in the sample increased after percolation of the ammonium nitrate solution, although only $\mathrm{NH}_{4}^{+}$was adsorbed onto the soil particles due to its positive charge. The only exception was UDS2, for which a decrease in the $\mathrm{N}-\mathrm{NO}_{3}$ concentration was observed, which indicates that ions were eluted from the sample. Moreover, it was clear that $\mathrm{NH}_{4}^{+}$ions were retained by soil particles with greater intensity than the $\mathrm{NO}_{3}^{-}$ions. The largest mass of $\mathrm{NH}_{4}^{+}$ was immobilized on the surface of UDS2, but notably the absorptive capacity of UDS1 was not exhausted.

\section{Conclusions}

The loss of nitrogen compounds from agricultural areas through leaching may become a significant environmental problem; therefore, identification of the factors influencing the concentration of nitrates $\left(\mathrm{NO}_{3}^{-}\right)$in the groundwater is a crucial issue. Batch test results have shown that $\mathrm{NO}_{3}$ sorption was negligible for all tested soils, whereas $\mathrm{NH}_{4}^{+}$ ions were removed by chemisorption processes. The results of column studies of the transport of chloride ions and nitrogen compounds through three different soil samples have indicated that a significant reduction in the $\mathrm{NO}_{3}{ }^{-}$and ammonium $\left(\mathrm{NH}_{4}^{+}\right)$concentrations in flowing groundwater has resulted from processes other than sorption and chemical precipitation, which could be indicated by gas production and a non-maximum concentration of $\mathrm{NO}_{3}^{-}$ (100 $\left.\mathrm{mg} \cdot \mathrm{L}^{-1}\right)$ and $\mathrm{NH}_{4}^{+}\left(52 \mathrm{mg} \cdot \mathrm{L}^{-1}\right)$ in the effluent liquid. Moreover, the values for the hydraulic coefficient of cohesive soils (UDS1 and UDS2) decreased as a result of the formation of gas bubbles in the soil pores.

Analysis of the results using CXTFIT software has allowed us to estimate the advection-dispersion equation parameters for contaminant transport for the analysed soil samples and calculation of the Péclet numbers, which indicated that advection was the dominating transport process for UDS1 and for the sand sample, and that dispersion dominated advection in the case of UDS2. 
Based on the retardation factor, the velocity of $\mathrm{NH}_{4}^{+}$ transport was lower than the velocity of water flow by approximately seven and five times for the UDS2 and sand sample samples, respectively; moreover, the estimated values of the retardation factor and dynamic sorption capacity $S_{\mathrm{m}}$ for $\mathrm{NO}_{3}^{-}$were lower than for $\mathrm{NH}_{4}^{+}$ions (because of the negative charge). Groundwater located beneath the soil layers composed of silt loam and loam is effectively protected against infiltration by nitrogen compounds from agricultural lands.

\section{Acknowledgements}

This research was co-financed by the European Regional Development Fund under the Innovative Economy Operational Programme: BIOPRODUCTS, innovative production technologies of pro-healthy bakery products and pasta with reduced caloric value (POIG.01.03.01-14-041/12).

\section{References}

1. ALLRED B.J. Laboratory evaluation of zero valent iron and sulfur-modified iron for agricultural drainage water treatment. Ground Water Monit. Remediat. 32 (2), 81, 2012.

2. WICK K., HEUMESSER K., SCHMID E. Groundwater nitrate contamination: Factors and indicators. J. Environ. Manage. 155, 178, 2012.

3. YANG X.L., LI T.K., HUA K.K., ZHANG Y.L. Investigation of first flushes in a small rural-agricultural catchment. Pol. J. Environ. Stud. 24 (1), 381, 2015.

4. MENG H., XU M., LÜ J., HE X., LI J., SHI X., PENG C., WANG B., ZHANG H. Soil $\mathrm{pH}$ dynamics and nitrogen transformation under long-term chemical fertilization in four typical Chinese croplands. J. Integr. Agr. 12 (11), 2092, 2013.

5. CAMARGO J., ALONSO Á. Ecological and toxicological effects of inorganic nitrogen pollution in aquatic ecosystems: A global assessment. Environ. Int. 32, 831, 2006.

6. MORADZADEH M., MOAZED H., SAYYAD G., KHALEDIAN M. Transport of nitrate and ammonium ions in a sandy loam soil treated with potassium zeolite Evaluating equilibrium and non-equilibrium equations. Acta Ecol. Sin. 34 (6), 342, 2014.

7. MATYSIK M., ABSALON D., RUMAN M. Surface water quality in relation to land cover in agricultural catchments (Liswarta river basin case study). Pol. J. Environ. Stud. 24 (1), 175, 2015.

8. NITRATE DIRECTIVE 91/676/EEC of December 12, 1991 on water protection from pollution caused by nitrate from agricultural sources.

9. IBENDAHL G., FLEMING R.A. Controlling aquifer nitrogen levels when fertilizing crops: a study of groundwater contamination and denitrification. Ecol. Model. 205, 507, 2007.

10. JAHANGIR M.M.R., KHALIL M.I., JOHNSTON P., CARDENAS L.M., HATCH D.J., BUTLER M., BARRETT M., O'FLAHERTY V., RICHARDS K.G. Denitrification potential in subsoils: A mechanism to reduce nitrate leaching to groundwater. Agricult. Ecosys. Environ. 147, 13, 2012.

11. JEGO G., SANCHEZ-PEREZ J.M., JUSTES E. Predicting soil water and mineral nitrogen contents with the STICS model for estimation nitrate leaching under agricultural fields. Agricult. Water. Manag. 107, 54, 2012.

12. CHEN Z., WANG C., GSCHWENDTNER S., WILLIBALD G., UNTEREGELSBACHER S., LU H., KOLAR A., SCHLOTER M., BUTTERBACH-BAHL K., DANNENMANN M. Relationships between denitrification gene expression, dissimilatory nitrate reduction to ammonium and nitrous oxide and dinitrogen production in montane grassland soils. Soil Biol. Biochem. 87, 67, 2015.

13. BERNARD-JANNIN L., SUN X., TEISSIER S., SAUVAGE S., SÁNCHEZ-PÉREZ J.-M. Spatio-temporal analysis of factors controlling nitrate dynamics and potential denitrification hot spots and hot moments in groundwater of an alluvial floodplain. Ecol. Eng. (in press) doi:10.1016/j. ecoleng.2015.12.031, 2015.

14. POCH-MASSEGÚ R., JIMÉNEZ-MARTÍNEZ J., WALLIS K.J., RAMÍREZ D.E. CARTAGENA F., CANDELA L. Irrigation return flow and nitrate leaching under different crops and irrigation methods in Western Mediterranean weather conditions. Agric. Water Manage. 134, 1, 2014.

15. CHEN S., WU W., HU K., LI W. The effects of land use change and irrigation water resource on nitrate contamination in shallow groundwater at county scale. Ecol. Complex. 7, 131, 2010.

16. CAVALLI D., CONSOLATI G., MARINO P., BECHINI L. Measurement and simulation of soluble, exchangeable, and non-exchangeable ammonium in three soils. Geoderma 259-260, 116, 2015.

17. LEE M.J., HWANG S.I., RO H.M. Interpreting the effect of soil texture on transport and removal of nitrate- $\mathrm{N}$ in saline coastal tidal flats under steady-state flow condition. Cont. Shelf Res. 84, 35, 2014.

18. YONG R.N., MULLIGAN C.N., FUKUE M. Sustainable practices in geoenvironmental engineering. CRC Press, 2015.

19. MILLS H.J., HUNTER E., HUMPHYS M., KERKHOF L., MCGUinNeSS L., HUETTEL M., KOSTKA J.E. Characterization of nitrifying, denitrifying and overall bacterial communities in permeable marine sediments of the northeastern Gulf of Mexico. Appl. Environ. Microbiol. 74, 4440, 2008

20. CUI Z., WELTY C., MAXWELL R.M. Modeling nitrogen transport and transformation in aquifers using a particletracking approach. Comput. Geosci. 70, 1, 2014.

21. BEDNAREK A., SZKLAREK S., ZALEWSKI M. Nitrogen pollution removal from areas of intensive farmingcomparison of various denitrification biotechnologies. Ecohydrol. Hydrobiol. 14 (2), 132, 2014.

22. DAVIES D.B. The nitrate issue in England and Wales. Soil Use Manage. 16, 142, 2000.

23. BURGIN A.J., HAMILTON S.K. Have we overemphasized the role of denitrification in aquatic ecosystems? A review of nitrate removal pathways. Front. Ecol. Environ. 5, 89, 2007.

24. US EPA/530/SW-87/006-F. Batch - type procedures for estimating soil adsorption of chemicals. US EPA (United States Environmental Protection Agency), Washington, DC. 1992.

25. ASTM D5084 - 00. Standard test methods for measurement of hydraulic conductivity of saturated porous materials using a flexible wall permeameter. American Society for Testing and Materials, Pennsylvania. 2001.

26. FRONCZYK J., GARBULEWSKI K. Selection of material suitable for permeable reactive barriers in vicinity of landfills. Ann. Warsaw Univ. of Life. Sci. - SGGW, Land Reclam. 41, 3, 2009. 
27. DANIEL D.E. State-of-the-art: laboratory hydraulic conductivity tests for saturated soils. In: DANIEL D.E., TRAUTWEIN S.J. (ed) Hydraulic conductivity and waste contaminant transport in soil ASTM STP 1142, Philadelphia, PA, 30, 1994.

28. TORIDE N., LEIJ F.J., VAN GENUCHTEN M.T. The CXTFIT code for estimating transport parameters from laboratory or field tracer experiments. Version 2.1. Research Report No. 137. Riverside, Cal.: USDA-ARS U.S. Salinity Laboratory. 1999.

29. U.S. DEPARTMENT of AGRICULTURE. Soil Conservation Service. Soil Survey Staff. Soil Survey Manual. U.S. Department of Agriculture. Agricultural Handbook No. 18. Washington, DC. 1951.

30. Eurocode 7. Geotechnical investigation and testing Identification and classification of soil - Part 1: Identification and description. ISO 14688-1, 2002.

31. WANG W.X., WANG X., YANG L., WU Z., XIA S., ZHAO J. $\mathrm{Cr}(\mathrm{VI})$ removal from aqueous solution with bamboo charcoal chemically modified by iron and cobalt with assistance of microwave. J. Environ. Sci. 25 (9), 1726, 2013.

32. HO Y.S., MCKAY G. Pseudo-second order model for sorption processes, Process Biochem. 34, 451, 1999.

33. ZHANG Y.Z., HUANG S.H., WAN D.J., HUANG Y.X., ZHOU W.J., ZOU Y.B. Fixed ammonium content and maximum capacity of ammonium fixation in major types of tillage soils in Hunan province, China. Agr. Sci. China 6 (4), 466, 2007.

34. SAID-PULLICINO D., CUCU M.A., SODANO M., BIRK J.J., GLASER B., CELI L. Nitrogen immobilization in paddy soils as affected by redox conditions and rice straw incorporation. Geoderma 228-229, 44, 2014.

35. CHENG J., ZHANG H., ZHANG Y., CHEN Y., WANG B. Characteristics of preferential flow paths and their impact on nitrate nitrogen transport on agricultural land. Pol. J. Environ. Stud. 23 (6), 1959, 2014.

36. MON J., FLURY M., HARSH J. B. Sorption of four triarylmethane dyes in a sandy soil determined by batch and column experiments. Geoderma. 133, 217, 2006.

37. FIORI A., BECKER M.W. Power law breakthrough curve tailing in a fracture: The role of advection. J. Hydrol. 525, 706, 2015.

38. DELGADO J.M.P.Q. Longitudinal and transverse dispersion in porous media. T. I. Chem. Eng.-Lond. Part A 85 (A9), 1245, 2007.

39. FREEZE R.A., CHERRY J.A. Groundwater. Prentice-Hall, Englewood Cliffs, NJ. 1979.

40. FRONCZYK J., GARBULEWSKI K. Evaluation of zeolitesand mixtures as reactive materials protecting groundwater at waste disposal sites. J. Environ. Sci. China 25 (9), 1764, 2013.

41. NGUYEN T.C., LOGANATHAN P., NGUYEN T.V., VIGNESWARAN S., KANDASAMY J. Simultaneous adsorption of $\mathrm{Cd}, \mathrm{Cr}, \mathrm{Cu}, \mathrm{Pb}$, and $\mathrm{Zn}$ by an iron-coated Australian zeolite in batch and fixed-bed column studies. Chem. Eng. J. 270, 393, 2015.

42. SYSWERDA S.P., BASSO B., HAMILTON S.K., TAUSIG J.B., ROBERTSON G.P. Long-term nitrate loss along an agricultural intensity gradient in the Upper Midwest USA. Agric. Ecosyst. Environ. 149, 10, 2012. 